(C) 2014

Щипакин М. В., Прусаков А. В., Вирунен С. В., кандидаты ветеринарных наук, Скуба В. В., Былинская Д. С., ассистенты

ФГБОУ ВПО «Санкт-Петербургская государственная академия ветеринарной медицины»

\title{
МЕТОДИКА ИЗГОТОВЛЕНИЯ КОРРОЗИОННЫХ ПРЕПАРАТОВ С ПРИМЕНЕНИЕМ СТОМАТОЛОГИЧЕСКИХ ПЛАСТМАСС
}

\author{
Рецензент - кандидат ветеринарних наук, профессор П. И. Локес
}

Изложена методика изготовления коррозионных анатомических препаратов с применением стоматологических пластмасс, которая на данный момент используется на кафедре анатомии животных ФГБОУВПО «Санкт-Петербургская государственная академия ветеринарной медицины». В качестве инъекиионной затвердевающей жидкости предлагаем использовать двухкомпонентную пластмассу «Редонт - 03», которая используется для изготовления ортодонтических протезов и состоит из двух компонентов - порочка и растворителя. В результате данной методики можно изготовить коррозионные препараты по сердечно-сосудистой системе, включая артериальное и венозное русло, а также слепки полостей трубкообразных органов. Кроме того, данную методику можно использовать для изготовления препаратов бронхиального древа и желчевыводящей системы печени. Полученные по данной методике коррозионные препараты можно использовать как в научно-исследовательской работе, так и при проведении лабораторно-практических занятий по анатомии животных.

Ключевые слова: коррозионные препараты, сердечно-сосудистая система, метод анатомического исследования.

Постановка проблемы. В литературных источниках описано большое количество методик изучения сердечно-сосудистой системы как человека, так и животных. Однако, с точки зрения морфологии, наиболее интересным является метод коррозионных препаратов. Это напрямую связанно с тем, что в результате применения данной методики изготавливается анатомический препарат, который по своей сути является отпечатком сосудистого русла.

Коррозионные препараты особенно удобны для изучения кровоснабжения органов, имеющих густую сеть сложно разветвляющихся сосудов. В этом случае методом препарирования очень трудно установить ход и ветвление сосудов, не нарушив целостности объекта исследования.

При исследовании препаратов сосудистого русла, полученных методом коррозии, можно выявить ход и ветвление сосудов в том или ином органе, а также судить об их пространственной организации. Однако, в связи с отсутствием в доступной литературе информации о практическом применении конкретных пластических материалов, воспроизведение подобных препаратов оказывается затруднительным. Поэтому тема данной статьи является актуальной.

Анализ основных исследований и публикаций по данной проблеме. Методика использования затвердевающих масс и изготовления коррозионных препаратов для изучения сердечнососудистой системы имеет давнюю историю. Ее родоначальником по праву можно считать И. Гиртеля [8], который предложил для наливки сосудистого русла использовать массу, состоящую из канифоли и воска (1873 г.). В дальнейшем эту методику усовершенствовала А. А. Красуская (1934 г.) [2, 3].

В качестве инъекционной массы А. Г. Акилова [1] в 1944 году предложила использовать растворенную в ацетоне или спирте с эфиром рентгеновскую пленку, предварительно очищенную от эмульсии, а В. Н. Степанова [7] в 1949 г. для изготовления мягких коррозионных препаратов предложила использовать синтетический каучук (севанит).

Результаты исследований зарубежных специалистов, как показал анализ спциальных источников, свидетельствуют о том, что с помощью стоматологических пластических масс удается получить препараты артериального русла почек, печени и языка животных [4-6].

Цель и задачи исследований. Целью исследований являлась разработка методики с применением широко распространенных пластических материалов для получения коррозионных препаратов кровеносных сосудов и полостей различных внутренних органов.

Основной задачей исследований было изучение и описание отдельных этапов изготовления препаратов для получения оптимальных результатов. 


\section{ВЕТЕРИНАРНА МЕДИЦИНА}

Материалы и методы исследований. В ходе выполнения работы на базе кафедры анатомии животных ФГБОУ ВПО «Санкт-Петербургская государственная академия ветеринарной медицины» для изготовления коррозионных препаратов применяли двухкомпонентную пластмассу «Редонт-03». Данная пластмасса используется для изготовления ортодонтических протезов и состоит из двух компонентов - порошка (пластической массы) и растворителя (на углеводородной основе). Материалом для исследованием послужили отдельные органы животных, полученные в результате аутопсии.

Результаты исследований. В ходе исследований было установлено, что пластмасса «Редонт-03» идеально подходит для изготовления коррозионных препаратов как артериальных, так и венозных сосудов. При этом перед наливкой осуществляли промывку сосудистого русла теплым $2 \%$ раствором нашатырного спирта (эта промывка необходима для удаления из сосудистого русла сгустков крови).

Для наливки кровеносных сосудов растворяли одну часть порошка в двух частях растворителя. При этом для получения прочного препарата необходимо достичь полного растворения твердой составляющей в растворителе. Для этого раствор необходимо размешивать стеклянной палочкой в течение 1-2 минут. После перемешивания массу набирали в шприц и вводили через канюлю в сосудистое русло. В связи с тем, что пластмасса «Редонт-03» быстро застывает в шприце и канюле, ее необходимо вводить быстро и под давлением.

Помимо сосудистого русла пластмассой «Редонт-03» заполняли полости различных трубкообразных органов. Полученные таким образом полимерные отпечатки полностью повторяют форму, а также пространственную организацию исследуемых органов и используются в качестве наглядного пособия при обучении студентов.

Кроме того данная методика подходит для исследования дыхательной системы. В этом случае можно изготовить полимерные отпечатки бронхиального древа. Данные препараты можно ис-

\section{БИБЛИОГРАФИЯ}

1. Акилова А. T. Методика изготовления коррозионных препаратов сосудов / А. Т. Акилова // Труды Военно-Морской Медицинской Академии. - Л., 1944. - Т. ІІІ. - Ч. 2. - С. 189-192.

2. Красуская А. А. Техника коррозионных препаратов / А. А. Красуская // Известия С.-Пб. биологической лаборатории. - С.-Пб., 1901. T. V. - Вып. 1. - C. 124-127. пользовать как для научно-исследовательской работы, так и в качестве демонстрационного материала при проведении лабораторно-практических занятий. Помимо этого «Редонт-03» можно использовать для наливки желчевыводящей системы печени.

После инфузии пластической массы материал подвергали фиксации в $10 \%$ растворе формалина в течение недели. По окончании фиксации препараты проваривали на медленном огне в течение часа. В дальнейшем препараты подвергали коррозионной обработке в водном растворе гидроокиси калия (в разведении 1:2) в течение 4-10 суток. В процессе коррозионной обработки проводили периодическое промывание препаратов в проточной воде для лучшего очищения полимерного отпечатка от лизированных окружающих тканей. При обработке все мягкие ткани под действием гидроокиси калия растворяются остается лишь полимерный отпечаток полостей исследуемого объекта.

В связи с тем, что пластмасса «Редонт-03» не даёт усадки и не деформируется в процессе застывания, можно производить морфометрию полученных препаратов.

Изготовленные коррозионные препараты уникальны, долговечны и хранятся в музее кафедры анатомии животных ФГБОУВПО «СанктПетербургская государственная академия ветеринарной медицины», а также активно используются как при проведении научно-исследовательской работы, так и в учебном процессе.

Выводы. Таким образом, описанная методика изготовления коррозионных препаратов с применением пластической массы «Редонт-03» позволяет получить результаты, которые с успехом могут применяться как в научно-исследовательской работе, так и учебном процессе.

Перспективы дальнейших исследований в данном направлении. Перспективами дальнейших исследований в данном направлении является поиск материалов, позволяющих сохранить пластические свойства коррозионных препаратов.

3. Красуская А. А. Техника коррозионных и просветленных препаратов / А. А. Красуская // Известия научн. ин-та им. Лесгафта. - Л., 1934. T. XVII, XVIII. - C. 215-217.

4. Локес П. I. Анатомо-топографічні особливості артеріальних судин нирок у домашніх кішок / П. І. Локес, Н. І. Дмитренко, С. О. Кравченко // Наукові праці Полтавської державної 


\section{ВЕТЕРИНАРНА МЕДИЦИНА}

аграрної академії. - Том 5 (24). Ветеринарні науки. - Полтава : РВВ ПДАА, 2006. - С. 74-79.

5. Локес П. І. Анатомо-топографічні зміни артеріальних судин при полікістозі нирок у домашніх кішок / П. І. Локес, С. О. Кравченко // Bicник Державного агроекологічного університету. - Житомир, 2007. - № 2. - Т. 2. - С. 137-141.

6. Пат. 37020 Україна, МПК (2006) A61F2/06 Спосіб відтворення повномасштабної моделі артеріальної системи нирок дрібних тварин /
П. І. Локес, С. О. Кравченко, Н. І. Дмитренко, I. I. Старченко, I. Г. Панасенко (Україна); Полтавська державна аграрна академія. №u2008 08280; Заявл 19.06.2008; Опубл. 10.11.2008, Бюл. № 21.

7. Степанова В. Н. К методике изучения сосудов плаценты / В. Н. Степанова // Акуш. и гинек. - Л., 1949. - № 5. - С. 49.

8. Hyrtl J. Die Corrosions - Anatomie und ihre Ergebnisse / J. Hyrtl. Wien, 1873. - P. 234. 